\title{
Thamy Pogrebinschi
}

\section{Participatory Policymaking and Political Experimentalism in Brazil}

Since the adoption of the new constitution in 1988, Brazilian political institutions have been increasingly becoming more stable and solid: these include a now very competitive multi-party system, periodic and universal elections, an active and plural congress, a strongly accepted and highly approved presidency, an increasingly respected Supreme Court, a fair system of judicial review, a legitimate legal order, a quite comprehensive system of rights, a free and open media, not to mention the massive turnout in elections due to the pedagogic experience of compulsory voting, and the always clear electoral processes.

Additionally, and especially from 2003 onwards, one can observe in Brazil a surprising proliferation and empowerment of social movements, a flourishing public sphere, and a breakthrough of participatory and deliberative practices that are increasingly institutionalized and supported by the state, from the local to the national level. As has been stated by the Minister of the General-Secretary of the Presidency of Brazil in late 2010, since Lula (Luiz Inácio Lula da Silva, from the Workers Party - PT - President of Brazil from 2003 to 2010) took office "social participation has been adopted as a democratic method of public administration".

Participation seems to have indeed become a democratic method of governance in Brazil. As a method, participation enriches representative democracy. While turning political institutions into more representative bodies, this participation accommodates civil society within the state, and impels the redesign of both policymaking and lawmaking processes. Such institutional changes have for their turn

1 This statement was made on August 20th, 2010, in an official address from Minister Luiz Dulci to the press. The full address is available at: $<$ www. secretariageral.gov.br/noticias/ultimas_noticias/2010/08/20-08-2010-nota-aimprensa-resposta-do-ministro-luiz-dulci-as-declaracoes-de-jose-serra> (13.07.2011). 
been proving themselves to produce not only more legitimate political decisions, but also more effective social outcomes. If Brazil's noted poverty reduction is due to income transfer and other successful redistributive policies adopted by Lula's government, the political representation of minority groups (such as women, indigenous people, LGBT, elderly, youth, people with disabilities, among others) is certainly also an achievement of the institutionalization of participatory experiences that allow for a more stronger and effective advocacy of rights and policy inclusion (Pogrebinschi forthcoming). Given such a scenario, I cannot help but recall Dewey: "there is nothing more radical than insistence upon democratic methods as the means by which rad cal social changes be effected" (Dewey 1937: 339).

In this paper my goal is to discuss a participatory experiment that has been intensely institutionalized in Brazil over the past few years, in particular since the Worker's Party (PT) took power in 2003. Such experiment is called "national conference on public policy" ("conferência nacional de políticas públicas"), and it is designed to provide guidelines for the formulation of public policy through a conjoint process of deliberation gathering together representatives from the government and from civil society. After raising some empirical evidence on the process of institutionalization of the national policy conferences in Brazil, my aim is to draw on some theoretical issues and argue that political experiments like in Brazil allow for a more responsive and inclusive political representation (that I call constitutive representation) and a more legitimate and stable democratic movement (that I call pragmatic democracy).

\section{Participatory Policymaking: the National Conferences on Public Policy}

The national public policy conference is the largest and possibly the most innovative participatory experience presently taking place in Brazil. It is organized by the executive branch along with civil society groups, and comprises a national level process of deliberation structured according to diverse policy areas and issues. A national conference is the culmination of a process that starts at the local (municipal) level, and goes through all states of the federation. Attendance at the national conferences is usually made up of $60 \%$ civil society repre- 
sentatives and $40 \%$ delegates from state and public administration. Civil society's representatives are usually elected in the first levels of the process (municipal and state) when the conferences are entirely open to participation (at the local level), and state's representatives are in general nominated. Some conferences also include a specific proportion of representatives of workers concerned with the policy issue under deliberation. On average, a national conference has about 3.000 delegates, but the entire process from the local to the national level involves hundreds of thousand of people, and the largest one up to now has reached over 500,000 participants on all levels (National Conference on Public Security, held on August 2009). After each of the conference stages (local, state, and national), a document containing the policy guidelines deliberated by all participants is approved in a final plenary session. The expectation is that the federal government uses such documents as a source to draft policies related to the areas and issues deliberated in the national conferences. Instead of relying on the expertise of technicians, the inputs from civil society hope to be taken into consideration in the policymaking process.

And indeed data indicates that during Lula's government the national policy conferences have been proving themselves successful enough to affect the policies drafted by the federal administration (Pogrebinschi forthcoming; 2012), and to influence the legislation enacted by Congress (Pogrebinschi/Santos 2010). Such positive impacts of the national policy conferences certainly result from their process of institutionalization over the past few years as will be made clear in the following pages.

The first so-called national policy conference was held in Brazil in 1941. It was a conference on health, a policy area that has pioneered the use of participatory practices in the country due to the very active professional associations and social movements that have historically engaged politically with health policy issues. Although at that time the so-called health national conferences did not follow the same national structure, participatory composition and deliberative format practiced today, those events cannot be dismissed when one considers the origin and the background of the current national policy conferences. And they must be taken into consideration so as one can observe the process of institutionalization of Brazilian participatory experiment. 
Over 50 years, between 1941 and 1991, only twelve national public policy conferences were held in Brazil, and all of them related to health policies. Between 1992 and 200980 national conferences were held in Brazil aimed at the deliberation of 33 diverse policy issues. ${ }^{2}$ Table 1 below presents the sample of national public policy conferences held in the country since the enactment of the 1988 Constitution until 2009, according to the policy issue addressed, the years in which they took place, and the frequency achieved by them.

Table 1: National Public Policy Conferences: issues and frequency

\begin{tabular}{|r|l|l|c|}
\hline & Conference/Policy Issues & Years & Total \\
\hline 1 & Aquaculture and Fisheries & $2003 / 2006 / 2009$ & 3 \\
\hline 2 & Social Assistance & $\begin{array}{l}1995 / 1997 / 2001 / 2003 / \\
2005 / 2007 / 2009\end{array}$ & 7 \\
\hline 3 & Cities & $2003 / 2005 / 2007$ & 3 \\
\hline 4 & $\begin{array}{l}\text { Science, Technology and Innova- } \\
\text { tion in Health }\end{array}$ & $1994 / 2004$ & 2 \\
\hline 5 & Communication & 2009 & 1 \\
\hline 6 & Brazilian Communities Abroad & $2008 / 2009$ & 2 \\
\hline 7 & Culture & 2005 & 1 \\
\hline 8 & $\begin{array}{l}\text { Sustainable and Solidarity Rural } \\
\text { Development }\end{array}$ & 2008 & 7 \\
\hline 9 & Children and Adolescent Rights & $1997 / 1999 / 2002 / 2003 /$ & 2 \\
\hline 10 & $\begin{array}{l}\text { Rights of Persons with Disabili- } \\
\text { ties }\end{array}$ & $2005 / 2007 / 2009$ & 2 \\
\hline 11 & Rights of the Elderly & $2006 / 2008$ & 11 \\
\hline 12 & $\begin{array}{l}\text { Human Rights } \\
\text { numb }\end{array}$ & $\begin{array}{l}1996 / 1997 / 1998 / 1999 / \\
2000 / 2001 / 2002 / 2003 /\end{array}$ & $2004 / 2006 / 2008$ \\
\hline
\end{tabular}

2 In reality, and according to official data, the number of national policy conferences held in Brazil up to 2009 is a bit higher (about 10\% higher). I do only take into consideration the national policy conferences that can be considered a) deliberative, b) normative and c) national in scope. For a description of these criteria and my methodology to classify the national policy conferences, see Pogrebinschi/Santos (2010). 


\begin{tabular}{|c|l|l|c|}
\hline N. & Conference/Policy Issues & Years & Total \\
\hline 13 & Solidarity Economy & 2006 & 1 \\
\hline 14 & Basic Education & 2008 & 1 \\
\hline 15 & Indigenous Education & 2009 & 1 \\
\hline 16 & $\begin{array}{l}\text { Professional and Technological } \\
\text { Education }\end{array}$ & 2006 & 1 \\
\hline 17 & Sports & $2004 / 2006$ & 2 \\
\hline 18 & $\begin{array}{l}\text { Gays, Lesbians, Bisexuals, Trans- } \\
\text { vestites, and Transsexuals }\end{array}$ & 2008 & 1 \\
\hline 19 & $\begin{array}{l}\text { Management of Healthcare Work } \\
\text { and Education }\end{array}$ & $1994 / 2006$ & 2 \\
\hline 20 & Youth & 2008 & 1 \\
\hline 21 & $\begin{array}{l}\text { Medications and Pharmaceutical } \\
\text { Care }\end{array}$ & 2003 & 1 \\
\hline 22 & Environment & $2003 / 2005 / 2008$ & 3 \\
\hline 23 & Public Policies for Women & $2004 / 2007$ & 2 \\
\hline 24 & Indigenous peoples & 2006 & 2 \\
\hline 25 & Promotion of Racial Equality & $2005 / 2009$ & 2 \\
\hline 26 & Health & $1992 / 1996 / 2000 / 2003 /$ & 5 \\
\hline 27 & Environmental Health & 2008 & $\mathbf{8 0}$ \\
\hline 28 & Dental Health & 2009 & $1993 / 2004$ \\
\hline 29 & Workers Health & $1994 / 2005$ & 2 \\
\hline 30 & Indigenous Health & $1993 / 2001 / 2005$ & 2 \\
\hline 31 & Mental Health & $1994 / 2004 / 2007$ & 2 \\
\hline 32 & Food and Nutritional Security & 2009 & 2 \\
\hline 33 & Public Security & & 2 \\
\hline Total & & 2 \\
\hline
\end{tabular}

The above data reveals that out of the 33 policy issues ever deliberated in national policy conferences, human rights is the policy area with the largest number of conferences aimed at its deliberation: 11 national conferences on human rights were held over a period of 12 years, even though social participation has certainly enlarged throughout this period. Social assistance and children and youth rights follow thereafter: there were 7 conferences for each of these 
policy areas. In the case of children and youth rights, the 7 conferences occurred within a 12-year period, whereas in the case of the social assistance conferences, 7 of them were distributed within a 14-year time span. Health, the pioneering policy area in the history of national conferences and the only one found in the period preceding 1988, was the object of only 5 conferences after that year. However, it is worth noting that, starting in the 1990s, health policies become the object of specialized conferences on different health issues, which comprise specific conferences on "oral health" (2), "workers health" (2), "health of indigenous peoples" (3), "mental health" (2), "environmental health" (1), in addition to "management of labor and education in health" (2), "science, technology, and innovation in health" (2), "medication and pharmaceutical care" (1), responding altogether for 20 conferences in 17 years. Conferences on policy for "aquaculture and fishing", "cities", "environment", "food and nutritional safety" come next, with 3 conferences each. There were 2 conferences held on "sports", "rights of the persons with disabilities", "rights of the elderly", "Brazilian communities abroad", "promotion of racial equality" and "policies for women". All remaining policy areas listed in table 1 had only one national conference during the timeframe examined: "culture", "solidarity economy", "professional and technological education", "youth", "solidarity and sustainable rural development", "gays, lesbians, bisexuals, transvestites and transsexuals, "public safety", "communication", and "indigenous peoples".

Once the national conferences are aggregated and classified in policy area sets and one analyzes their frequency distribution, it becomes clear that "health" and "minorities" policy area sets lead the field, each one with 20 occurrences, divided into 9 different policy issues. Among the conferences within the health policy area set there have been the 5 aforementioned health conferences in addition to 15 specialized conferences in the subject, also summing up 20 conferences. The "minorities" policy area set includes the national conferences on the "rights of the elderly", "rights of people with disabilities", "gays, lesbians, bisexuals, transvestites and transsexuals", "indigenous people", "public policies for women", "children and youth rights", "promotion of racial equality", "youth", and "Brazilian communities abroad" therefore 20 conferences for 9 policy areas, being that 8 of them (the exception is only "children and youth rights") have only began to be 
addressed on national conferences in 2003. The policy area sets "state, economy and development" and "education, culture, social assistance and sports" come next, tied with 13 conferences apiece. The former policy area set is further divided into 7 policy issues: "solidarity economy", "aquaculture and fishing", "sustainable and solidarity rural development", "food and nutritional safety", "cities", "public safety" and "communications". The latter for its turn is further divided into 6 policy issues: "basic education", "professional and technological education", "indigenous education", "culture", "sports" and "social assistance". The national conferences on "human rights", due to its intense and stable frequency (11 editions, most of them held every two years since 1996), the vast number of policy guidelines produced, count as one in itself. The "environment" also constitutes a single separate policy area set due to its lack of convergence with the other policy areas, although only 3 conferences on this issue were held up to 2009.

Once the national conferences are classified according to policy area sets based on the convergence of the issues they deal with, it is possible to notice in the graph 1 below that, together, "health" and "minorities" are responsible for precisely half of all national policy conferences held thus far, with each one accounting for $25 \%$ of the total. In the first case, there is nothing striking about the fact that the pioneering policy area in national conferences is responsible for a fourth of the total figure, especially given the early and strong institutionalization of professional associations and social movements concerned with health policies. However, this is not the case with the "minorities" policy area set. It is indeed striking that the 9 policy issues it comprises account for a fourth of all national conferences held after 1988 given that 8 of their policy issues only started being deliberated in national conferences after 2003. One notices that since the beginning of the first term of Lula's government (2003), the national policy conferences became notably more comprehensive in terms of policies addressed, and also more plural and heterogeneous accordingly to the positive response of government to the demands of minority groups that claimed to have their interests and rights addressed in national conferences. 
Table 2: National conferences:

distribution according to policy area sets

\begin{tabular}{|c|c|c|c|}
\hline Policy area & Issues & $\begin{array}{l}\text { Quantity } \\
\text { of Issues }\end{array}$ & $\begin{array}{l}\text { Quantity of } \\
\text { Conferences }\end{array}$ \\
\hline Health & $\begin{array}{c}\text { Health } \\
\text { Oral health } \\
\text { Workers health } \\
\text { Health of indigenous peoples } \\
\text { Mental health } \\
\text { Environmental health } \\
\text { Science, technology, and innovation } \\
\text { in health Management of labor and } \\
\text { education in health } \\
\text { Medication and pharmaceutical care }\end{array}$ & 9 & 20 \\
\hline Minorities & $\begin{array}{c}\text { Rights of the Elderly } \\
\text { Rights of people with disabilities } \\
\text { Gays, lesbians, bisexuals, } \\
\text { transvestites and transsexuals } \\
\text { Indigenous people } \\
\text { Public policies for women } \\
\text { Rights of children and adolescents } \\
\text { Youth } \\
\text { Promotion of Racial Equality } \\
\text { Brazilian Communities Abroad }\end{array}$ & 9 & 20 \\
\hline Environment & Environment & 1 & 3 \\
\hline $\begin{array}{c}\text { State, } \\
\text { Economy } \\
\text { and } \\
\text { Development }\end{array}$ & $\begin{array}{c}\text { Solidarity Economy } \\
\text { Aquaculture and fishing } \\
\text { Sustainable and solidarity rural } \\
\text { development Food and nutritional } \\
\text { safety } \\
\text { Cities } \\
\text { Public Security } \\
\text { Communications }\end{array}$ & 7 & 13 \\
\hline $\begin{array}{c}\text { Education, } \\
\text { culture, } \\
\text { social } \\
\text { assistance and } \\
\text { sports }\end{array}$ & $\begin{array}{c}\text { Basic Education } \\
\text { Professional and Technological } \\
\text { Education } \\
\text { Indigenous Education } \\
\text { Culture } \\
\text { Sports } \\
\text { Social Assistance }\end{array}$ & 6 & 13 \\
\hline Human Rights & Human Rights & 1 & 11 \\
\hline
\end{tabular}


Graph 1: National conferences: distribution according to policy area sets

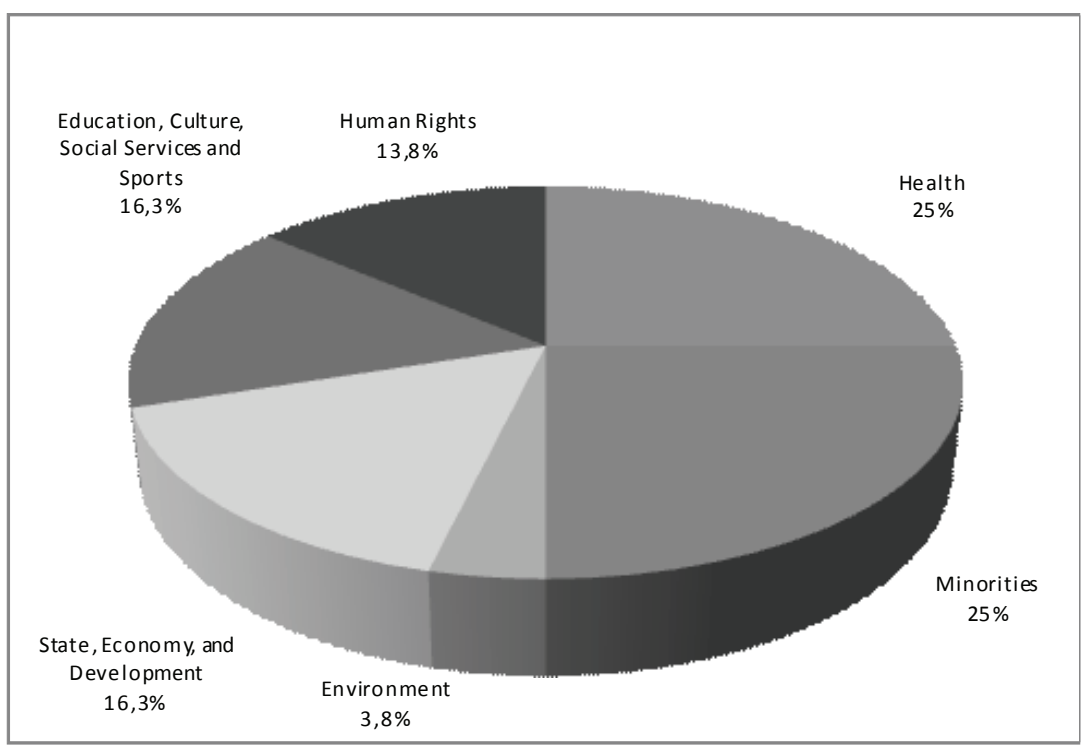

The pattern of distribution at the national conferences according to policy areas and frequency becomes more meaningful when they are listed in relation to the governments during which period in office they were held. The graph 2 below indicates that out of the 80 national policy conferences held from 1988 to 2009,55 took place during Lula's government (2003-2009). This means that $68.8 \%$ of all national policy conferences held during 21 years occurred within a 7 years period, an average of 8 conferences per year. ${ }^{3}$ In the 8 years of Fernando Henrique Cardoso's government (1995-2002) 17 conferences took place, that is, $21.3 \%$ of the total, averaging slightly above 2 conferences per year. The Itamar Franco government comes next (19921992), with 6 conferences held in 2 years and 2 months of mandate, comprising $7.5 \%$ of the total, followed by the Fernando Collor de Mello government (1990-1992), with only 2 conferences held during

3 In fact, official data and historical records would indicate an average of 10 national policy conferences per year since Lula took office, but as I have mentioned before the sample analyzed here only considers those conferences that are deliberative, normative, and national. 
his 2 year and 9 month long stint in office, accounting for $2.5 \%$ of the sample of national conferences that took place in Brazil from 1988 to 2009. One observes that, in as much as conferences begin to be institutionalized in the time of Fernando Henrique Cardoso's government (as it is the case for the national conferences on the rights of children and adolescents, as well as those on human rights), it was not until Lula's first term in presidency that their frequency became more significant, thus becoming incorporated into the Brazilian political agenda. No conferences were held from 1988 until the beginning of the Collor government in 1990, which explains why José Sarney's period in office (1985-1990) was excluded from these statistics.

Graph 2: National Conferences: distribution according to governments

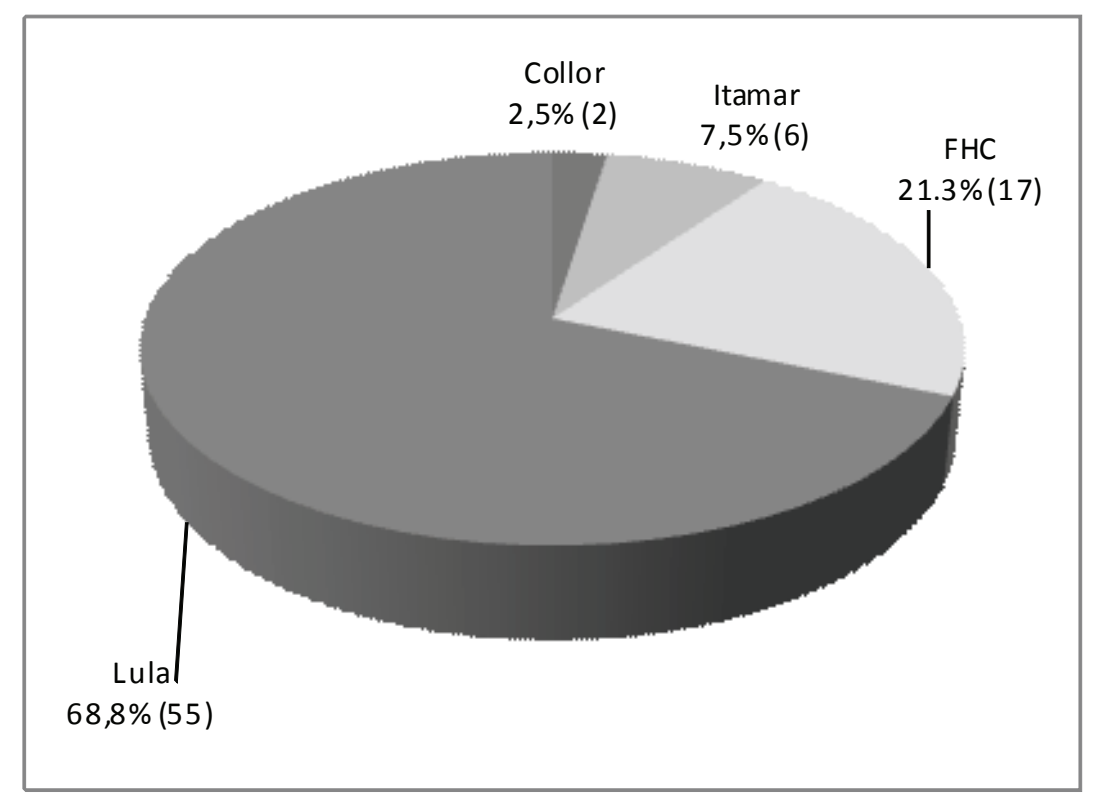

The pattern of distribution of the national conferences according to governments brings greater meaningfulness to the classification of policy area sets once the quantity of issues dealt with is analyzed. Table 3, below, reveals that of the 33 policy issues that were objects of national conferences in the last 21 years, 32 of them, that is, $97 \%$, were deliberated during Lula's government. The only issue not dealt 
with during this government up to 2009 was "mental health", which had previously been the object of two conferences, one in 1999 and the other one in 2001. ${ }^{4}$ However, looking at the policy guidelines that resulted from the national policy conferences one can see that mental health was addressed by several other national conferences held from 2003 to 2009 (Lula's period in office), as in the case of the conferences of "medication and pharmaceutical care" (2003), "human rights" (2003), "workers health" (2005), "rights of people with disabilities" (2006), and "gays, lesbians, bisexuals, transsexuals, and transvestites" (2008). It can therefore be stated (and this is entirely true if one takes 2010 into consideration) that Lula's government addressed the entire range of policy areas and issues dealt with in the history of national policy conferences in Brazil. The expansiveness of the policy areas and issues covered in the national conferences is certainly a sign of the process of institutionalization that they have been going through.

Besides Lula's, the other governments account for varying proportions of policy issues deliberated in national conferences out of the remaining 33 that constitute the sample. Two issues were tackled by Fernando Collor's government, each one in a separate national conference, which corresponds to $6 \%$ of the total sample of issues. Itamar Franco's government addressed 6 issues in 6 separate conferences, thus accounting for $18.2 \%$ of the total amount of issues in the sample. The data shows that these two governments, however, held national conferences that were almost exclusively dedicated to issues within the "health" policy area set. Other policy issues and areas will only be considered in the national conferences held during the two presidential terms of Fernando Henrique Cardoso, which account for 7 issues, that make up for $21.2 \%$ of the sample. Of these 7 policy issues deliberated during Cardoso's government, 3 belong to the "health" policy area set, 1 to the "minorities" policy area set, 1 to the "human rights" policy area set, 1 to the "state, economy, and development" policy area set, and finally 1 to the "education, culture, social assistance, and sports" policy area set. Table 3 displays these data.

4 Although the sample under analysis considers only the national policy conferences held until the end of 2009 , it is worth mentioning that the third national conference on mental health was held in 2010, in the last year of Lula's second mandate. 
Table 3: Policy issues deliberated by governments

\begin{tabular}{|c|c|c|c|}
\hline Presidency & \begin{tabular}{|c|}
$\begin{array}{c}\text { Quantity of } \\
\text { Conferences } \\
(\%)\end{array}$ \\
\end{tabular} & $\begin{array}{c}\begin{array}{c}\text { Quantity } \\
\text { of Issues } \\
(\%)\end{array} \\
\end{array}$ & Policy Issues \\
\hline $\begin{array}{l}\text { Fernando } \\
\text { Collor }\end{array}$ & $2(2.5 \%)$ & $2(6 \%)$ & $\begin{array}{c}\text { Health (1992) } \\
\text { Mental health (1992) }\end{array}$ \\
\hline $\begin{array}{l}\text { Itamar } \\
\text { Franco }\end{array}$ & $6(7.5 \%)$ & $6(18.2 \%)$ & $\begin{array}{c}\text { Oral health (1993) } \\
\text { Indigenous health (1993) } \\
\text { Workers health (1994) } \\
\text { Management of labor and education in } \\
\text { health (1994) } \\
\text { Science, technology, and innovation in } \\
\text { health (1994) } \\
\text { Food and nutritional safety (1994) }\end{array}$ \\
\hline $\begin{array}{l}\text { Fernando } \\
\text { Henrique } \\
\text { Cardoso }\end{array}$ & $17(21.3 \%)$ & $7(21.2 \%)$ & $\begin{array}{c}\text { Social assistance } \\
(1995,1997,2001) \\
\text { Rights of children and adolescents } \\
(1997,1999,2001) \\
\text { Human rights }(1996,1997,1998,1999, \\
\text { 2000, 2001,2002) } \\
\text { Health }(1996,2000) \\
\text { Indigenous health (2001) } \\
\text { Mental health (2001) } \\
\text { Food and nutritional safety (1994) }\end{array}$ \\
\hline $\begin{array}{l}\text { Lula Inácio } \\
\text { Lula da } \\
\text { Silva } \\
\text { (until 2009) }\end{array}$ & $55(68.8 \%)$ & $32(97 \%)$ & $\begin{array}{c}\text { Health }(2003,2008) \\
\text { Oral health }(2004) \\
\text { Workers health }(2006) \\
\text { Health of indigenous peoples }(2005) \\
\text { Environmental health (2009) } \\
\text { Science, technology, and innovation in } \\
\text { health (2004) } \\
\text { Management of labor and education in } \\
\text { health (2006) } \\
\text { Medication and pharmaceutical care } \\
\text { (2003) } \\
\text { Rights of the Elderly (2006, 2009) } \\
\text { Rights of people with disabilities } \\
\text { (2006, 2008) } \\
\text { Gays, lesbians, bisexuals, transvestites } \\
\text { and transsexuals (2008) } \\
\text { Indigenous people (2006) } \\
\text { Public policies for women (2004, } \\
\text { 2007) }\end{array}$ \\
\hline
\end{tabular}




\begin{tabular}{|c|c|c|c|}
\hline Presidency & $\begin{array}{c}\text { Quantity of } \\
\text { Conferences } \\
(\%)\end{array}$ & $\begin{array}{c}\text { Quantity } \\
\text { of Issues } \\
(\%) \\
\end{array}$ & Policy Issues \\
\hline $\begin{array}{l}\text { Lula Inácio } \\
\text { Lula da } \\
\text { Silva } \\
\text { (until 2009) }\end{array}$ & $55(68.8 \%)$ & $32(97 \%)$ & $\begin{array}{c}\text { Rights of children and adolescents } \\
(2003,2005,2007,2009) \\
\text { Youth }(2008) \\
\text { Promotion of Racial Equality } \\
(2005,2009) \\
\text { Brazilian Communities Abroad } \\
(2008,2009) \\
\text { Environment } \\
(2003,2005,2008) \\
\text { Solidarity Economy (2006) } \\
\text { Aquaculture and fishing } \\
\text { (2003, 2006, 2009) } \\
\text { Sustainable and solidarity rural } \\
\text { development }(2008) \\
\text { Food and nutritional safety } \\
\text { (2004, 2007) } \\
\text { Cities (2003, 2005, 2007) } \\
\text { Public Security }(2009) \\
\text { Communications }(2009) \\
\text { Basic Education }(2008) \\
\text { Professional and Technological } \\
\text { Education }(2006) \\
\text { Indigenous Education (2009) } \\
\text { Culture }(2005) \\
\text { Sports }(2004,2006) \\
\text { Social Assistance } \\
\text { (2003, 2005, 2007, 2009) } \\
\text { Human Rights } \\
\text { (2003, 2004, 2006, 2008) }\end{array}$ \\
\hline Total & 80 & 33 & \\
\hline
\end{tabular}

Table 3 indicates that considering the 8 policy issues deliberated in the national policy conferences held during the governments of Fernando Collor ("heath" and "mental health") and Itamar Franco ("oral health", "indigenous health", "workers health", "management of education and labor in health", "science, technology and innovation in health", and "food and nutritional safety"), Fernando Henrique Cardoso's government makes up for only 3 policy issues addressed ("social 
assistance", "children and youth rights", and "human rights"). This means that 22 out of 33 policy issues taken on by national conferences in 21 years were introduced during the first 7 years of Lula's government, that is, from 2003 onwards. Based on the previous classification of policy area sets, it is possible to notice that almost all national policy conferences classified under "minorities" (except for "children and youth rights"), "education, culture, social assistance and sports" (except for "food and nutritional health") and "environment" sets took place during Lula's government. Likewise, among the 8 policy issues that make up the "minorities" policy area set only one was deliberated in national policy conferences by governments preceding Lula's. Furthermore, with respect to the 8 policy issues included in the health policy area set, 2 became the object of conferences for the first time after 2003, despite the fact this is the area in which the very first national policy conferences have occurred. The pluralization of policy issues deliberated is also a sign of the process of institutionalization of the national public policy conferences.

It is worth noting that, in the period preceding 1988, 12 national conferences were held in Brazil, in which 5 issues were deliberated ("health", "oral health", "workers health", "indigenous health" and "mental health"), all of which are part of the health policy area set. If one is to consider the fact that out of the 8 policy issues considered by the governments of Fernando Collor de Mello and Itamar Franco, 5 had already been the object of national policy conferences before 1988. Fernando Henrique Cardoso's government had in reality only introduced 3 new policy issues to the entire range of 33 dealt with in national public policy conferences in Brazil. Lula's government was therefore responsible for introducing $66.7 \%$ of the policy issues that have been object of national public policy conferences in Brazil, considering its entire history both before and after 1988. This data is conveyed by the graph 3 . The policy innovation and groups inclusion and representation revealed by such data is derived from the close and strong relationship Lula's government has been maintaining with civil society over the years, allowing a considerable amount of professional and workers associations, as well as Non Governmental Organizations (NGOs) and social movements, to take an active part in the national public policy conferences. 


\section{Graph 3: Introduction of new issues by governments}

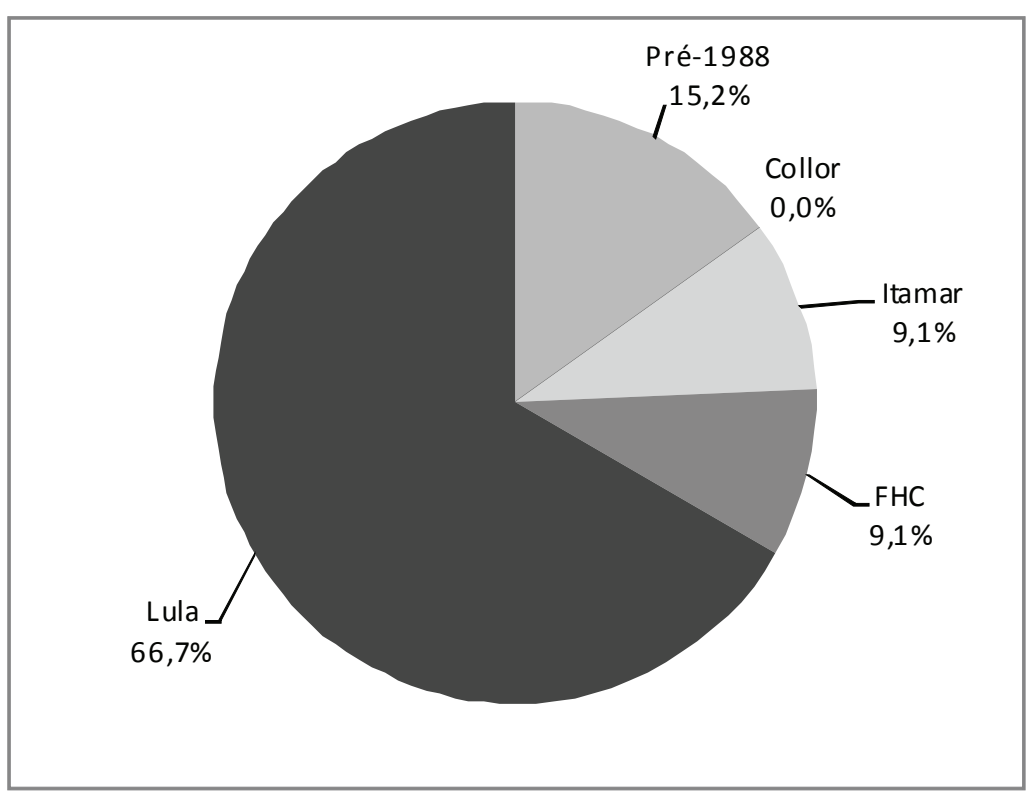

Of the 22 new policy issues that began to be addressed in national conferences after 2003 , the fact that 8 issues, that is $36.4 \%$ of the total, is concerned with minority groups is rather remarkable. Those 8 policy issues are distributed amongst 13 conferences, namely: the National Conference for the Promotion of Racial Equality (2005 and 2009), the National Conference for the Rights of the Elderly (2006 and 2009), the National Conference for Gays, Lesbians, Bisexuals, Transsexuals and Transvestites (2008), the National Conference for the Indigenous (2006), the National Conference for Women Public Policy (2004 and 2007) and the Conference for Brazilian Communities Abroad (2008 and 2009). This figure is particularly relevant. It shows that participatory experiments, such as the national policy conferences, are capable of strengthening political representation. This is so because they situate the executive (in charge of summoning and organizing the national conferences) and the legislative (able to convert the demands originating in the conferences into legislative proposals) as spheres of representation not only for political minorities, 
but also for social and cultural minorities - or, more to the point, minority groups whose interests are eventually but not directly taken into account in party politics. The participatory processes such as the national conferences are considered privileged spaces in which those interests can be defined and thereafter reach the elected representatives through other channels, ultimately being able to reconfigure how political parties mediate interests (Pogrebinschi forthcoming).

This piece of information also displays the increasing institutionalization of the national policy conferences: they have become not only extensive and more frequent, but also more wide-ranging and inclusive after 2003 with the beginning of the Lula's government. Since then, national conferences have comprised an increasing number of policy areas and have covered a vast plurality of new issues for public policy design, several of them social and cultural policies targeted at minorities. The contours of these policy areas are defined to a large extent by the particular nature of the minority groups that take part into the national conferences and yet, at the same time, exhibit features that cross-cut and cross over to different policy issues dealt with in various conferences.

The policy guidelines deliberated and approved in the national conferences under the "minority" policy area set aim to respond to the demands of the women (at the national conferences of public policies for women), the indigenous people (at the conference for indigenous peoples), the elderly (at the conferences for the rights of the elderly), the people with disabilities (at the conferences for the rights of persons with disabilities), the gays, lesbians, bisexuals, transvestites and transsexuals (at the conference named so), of children and youth (at the conferences on children and youth rights) of different races and ethnicities (at the conferences for the promotion of racial equality), and of Brazilian communities abroad (at the conferences on Brazilian communities abroad). Such specific minority policy guidelines necessarily touch other public policy areas, such as health, education, social assistance and culture. Hence, starting in 2003, the national policy conferences have become not only wideranging, but more inclusive as well, since, in addition to including increasingly more diverse and heterogeneous social groups traditionally represented by civil society (distributed among NGOs, social 
movements, workers' unions, business entities and other professional or non-professional entities), they have began functioning as spaces in which social and cultural minorities can represent their hitherto fragmented and scattered interests that had not been channeled into other forms of political participation and representation (Pogrebinschi forthcoming).

With an examination of the policy guidelines that have been approved at the end of the deliberation procedures in national public policy conferences, it is possible to notice how these participatory experiments in fact present themselves as spaces that favor the formulation of legislative expectations for the social and cultural minorities. The policy area set classified as "minorities", which comprises, as demonstrated earlier, 9 issues which are further subdivided into 20 conferences (17 of them on 8 issues, taking place after 2003), responds alone for $18 \%$ of policy guidelines which claim for incisive legislative action. This number is quite significant for at least two reasons.

First, because those minority groups have become, during the same period the objects of new secretariats and national councils created in Brazil's federal executive branch with the goal of bringing them closer to the government and designing public policies according to their interests and demands. This is the case, for example, of the Special Secretariat for Public Policies for Women and the Secretariat for the Promotion of Racial Equality, which have been very active alongside national policy councils dedicated to these same issues. One can thus assume that the demands of those groups have been fairly considered by specific administrative measures, which actually seem naturally more suited to the task of designing specific social and cultural policies. It is thus it significant that there is a large number of minority groups demands that still require legislative responses - in other words, a large number of claims for rights and recognition, and a strong indication that there is a persistent need in Brazil to formally include minority groups.

Second, the demands of those minority groups are frequent and, by nature, rather particular and require actions that are somewhat more sector-specific. This is another reason that would explain the need to contemplate these demands through administrative measures, and not legislative ones. The fact that the number of policy guidelines 
classified as part of the "minority" policy area set is almost as large as those relative to the "health" one indicates a tendency towards the dissemination of the demands presented by minority groups. Health is certainly one of the areas which, given the universal nature of its policies, requires its demands to be addressed in the legislative sphere. This explains why a larger number of policy guidelines have been identified for this policy area set, reaching $21 \%$ of the total. Graph 4 presents this data.

Graph 4: Distribution of policy guidelines directed to the Legislative Branch according to policy area sets

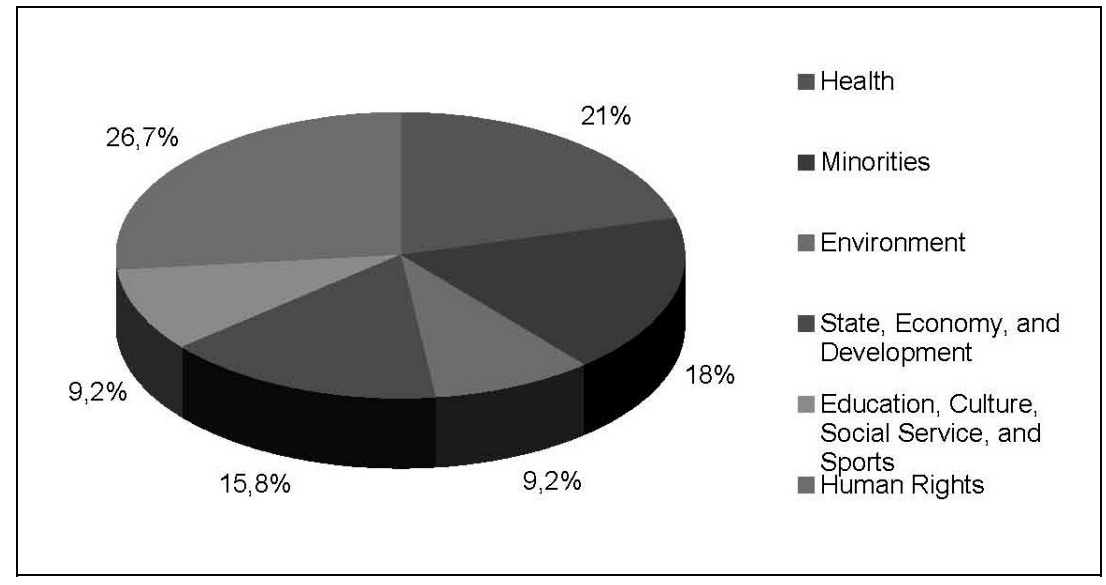

As one can see, by way of the national conferences civil society groups have an important part in public policy design, and play a fundamental role in the process through which political decisions have been taken in Brazil. While transforming liberal democracy from the inside, Brazilian democracy has been allowing for a dialectical relation among state and civil society, whose supposed contradiction might be overcome by the increase of mediations such as the participatory experiments that take place along with representative institutions. The national policy conferences enlarge citizens' and group's direct participation, however that does not mean that the traditional political institutions have become less able to represent them. 


\section{Constitutive Representation and Pragmatic Democracy}

The process of institutionalization at the national conferences on public policy in Brazil reveals these as a participatory experiment that may potentially strengthen political representation. First, the national policy conferences do not present themselves as an alternative side of representative institutions since they have been created within them: it is the executive branch that summon, convene, and organize the national conferences together with civil society organizations involved and affected by the policy area to be deliberated in the conferential process. Second, they do not compete against representative institutions since they act in cooperation with them: the legislative branch has been quite responsive to the demands brought up by civil society in the national conferences (Pogrebinschi/Santos 2010), and the executive has been consistently turning the guidelines deliberated in those participatory practices into policies to be applied in national scale (and this is precisely its purpose when it summons the conferences to convene) (Pogrebinschi forthcoming). Third, they do not imply a parallel type of representation since they do not engender simply "informal" or "social" types of representation: through the national policy conferences, minority groups have a chance to have their interests politically represented through representatives in both the legislative and executive branches that have not been elected by them nor have been elected to represent the type of interests favored by them.

The national policy conferences are thus a case that empirically supports an argument I have been making on a theoretical level (Pogrebinschi 2010a): participation and deliberation should be taken as constitutive parts of representation. In fact, they have always been so - elections, lobby and interests groups are certainly forms of participation, as well as parliamentary commissions and floor activities have always involved deliberation. In the past few years, however, new forms of participation and deliberation have arisen, and although they consistently require the intervention of representative institutions in order to be conclusive, decisional and binding, they are often thought of as pointing to a different (because less representative or indirect) form of democracy. Over the last years there has been significant work done on the representative dimension of both participa- 
tory practices and civil society actors, and particularly on the need to recast and re-theorize political representation in face of the challenges brought about by the participatory and deliberative practices of democracy, among other things (Avritzer 2007; Castiglione/Warren 2006; Mansbridge 2003; Urbinati 2006; Urbinati/Warren 2008).

Such new participatory and deliberative practices certainly avoid the electoral side of representative democracy when they are implemented in civil society, as have been correctly pointed out by several political theorists (Avritzer 2007; Barber 1984; Bohman 1996; Castiglione/Warren 2006; Cohen 1997; Dryzek 2000; Fishkin 1991; Gutmann 1996; Habermas 1998; Manin 1996; Rosanvallon 1998; 2006; Sintomer 2007; Urbinati 2006). However, such practices can only be considered politically representative when they are conclusive, and thus produce decisions on political issues that impact on the political system even if they are not binding. There is yet no other way to do so then through representative institutions and elected representatives. Those, for their turn, have been showing themselves over the last few years as more open and responsive to the participatory and deliberative practices. The most known, successful and replicated case of participation, the participatory budgeting, was after all the product of a specific government, and its implementation and success have been proven to be dependent on the election of certain political parties (Avritzer 2009).

Participatory and deliberative practices of democracy are often linked to civil society's ability to associate, mobilize and coordinate social groups and institutions, as if it were able to govern itself through its own self-empowerment, regardless of the state. The precise role both state and civil society have been playing in the national policy conferences' institutionalization is, however, shaped throughout the process. Even though all conferences are summoned to convene by a normative act issued by the Executive branch, some of them are a clear result of civil society's demands that have been fairly responded by the government. This cooperative undertaking is ultimately what defines which policy areas and issues will be prioritized, and will later possibly become object of the national policy plans and programs to be implemented in Brazil.

However, the political and redistributive effects of participatory experiments can only be undertaken by the state, and it is certainly 
partly the awareness of this fact that has been giving rise to the process of their increasing institutionalization. In Latin America, where participatory experiences proliferate and scale up as to reach the national level, institutionalization seems to be the rule. And this rule is in most of the cases designed and applied by the state, which houses civil society's initiatives and propose new ones along with it. Institutionalized participation is thus something that goes together with the state.

As participatory and deliberative practices become political in their scope and institutionalized in their form, one moves towards a form of constitutive representation. Such kind of representation takes institutionalized political participation and deliberation as its constitutive parts. And it is constitutive representation that lies at the basis of the most recent transformation of representative government, one in which the mediations between state and civil society have been changing so as to also transforms the relationship between those that have at least since the foundation of political modernity been seen as separate spheres.

I do therefore agree with Manin (1996) when he claims that there is historically no crisis of representative democracy, but a metamorphosis of representative government. However, despite his description of the démocratie du public (based on communicative expertise) as its last stage, I believe it is time to go further and recognize another transition not only in the meaning of political representation, but also in the kind of government it implies. That is why I would like to argue that constitutive representation is one of the manifestations of a pragmatic model of democracy.

What I call pragmatic democracy involves both a normative conception of democracy and an analytical approach to comprehending and evaluating it, which, despite its pragmatist inspiration, does not imply any particular conception of democracy endorsed by the thinkers commonly associated to this philosophical tradition. By democracy I understand a form of mediation between the state and civil society, and I assume pragmatism might be a fruitful theoretical tool in explaining the type of relationship between the state and civil society observed in the contemporary world and, particularly, in Brazil. If democracy is a form of mediation between the state and civil society, by pragmatic democracy I understand a mediation which, from a 
normative perspective, is meant to overcome the contradiction between the state and civil society through the suppression of the false dualism between representation, on one hand, and participation and deliberation, on the other one.

More specifically, by democracy I understand an open-ended set of institutions, experiences and practices whose scope is the mediation between the state and civil society. The performance of democracy varies according to how well such mediation functions. Democracy's success, in turn, is measured by how successful the overcoming of the antagonism between the state and civil society is. The more a given institution, experience or practice succeeds in closing the gap between the state and civil society, the greater is its capacity to promote democracy. In other words, the narrower the structural separation and functional differentiation between the state and civil society, the greater the degree of democracy achieved by a given political regime.

The irrefutably normative character of pragmatic democracy is also manifest in the fact that it builds upon a critique of the normative character of contemporary theoretical work on deliberative and participatory democracy with intention of championing a broad conception of political representation that is informed by empirically sustained institutional analyses. Thus, whereas the concept of pragmatic democracy is assumedly normative in its scope, this does not apply to the extent of its range. As much as what I call pragmatic democracy, in its conceptual genesis, is vulnerable to being used as a reference for other equally normative theoretical work on democracy, this does not prevent its employment as an analytical tool useful in describing the behavior of existing institutions and political practices, particularly those in Brazil.

As Brazil's national public policy conferences become increasingly institutionalized, they present themselves as a very relevant mediation between the state and civil society, and one in which participation and deliberation come true as representation. If the propelled crisis of political representation is not extensive to Brazil, perhaps this is the case because the country has been successful in institutionalizing participation and deliberation, which has transformed both politically in scope because they deal with essential political issues and make an impact on the policymaking. Instead of 
a crisis, the country faces a transformation in its representative government, one that moves it away from liberal democracy dualisms (such as state versus civil society, political versus social, universal versus particular, individuals versus groups, representation versus participation), and brings it closer to a pragmatic democracy in which such false contradictions might be dialectically overcome through political experimentalism.

Political experimentalism as a method of pragmatic democracy implies converting facts into norms, practices into institutions, and ends into means. It calls for the political empowerment of social groups by furthering the institutionalization of democratic practices conducted in, for, and through civil society. Experimentalism is the invention of the new and the transformation of the old, the replacement of normativity with factuality. Situated somewhere between the ideals of revolution and reform, experimentalism is politics conjugated in the future perfect tense: contingence renders democracy at once an experience and an experiment.

Applied at the political level, experimentalism requires the adoption of a critical stance towards principles and a practical attitude towards facts. To critically interrogate principles implies substituting action for speculation and contemplation. Facts shall be the driving force behind any political action aspiring social intelligence; these facts aim at creative interventions into the future through the transformation of present conditions, and that implies substituting experimental methods of democracy for the fixity of the liberal principles that for centuries have been shaping it. Facts revise principles, and once they are conferred normative strength one might rely on them as sources of legitimacy for political action. In other words, taking facts as the driving force of political action means assuming the social demands present in each and every context as determinants of institutional choices and decisions. If facts are the bearers of social demands, they must also be the conductors of political and institutional innovations.

Taking political experimentalism as a method requires facts to be heard and to be taken seriously, and such disposition to lead contingency drive political decisions ultimately is conducive to pragmatic democracy. A pragmatic democracy questions the principle of a separation of power, much like what happens when the executive 
branch and the legislature cooperatively define Brazil's policy agenda in convergence with the deliberations that take place in the national policy conferences. A pragmatic democracy challenges the centrality of individual rights when social and cultural groups' rights become a key focus of both policymaking and lawmaking, turning particular demands into universal policies and thus redefining the meaning of political equality. A pragmatic democracy interrogates the electoral foundation of liberal democracy, allowing interests to bypass the party system and achieve representation in the legislature through participatory institutions. A pragmatic democracy redefines representation as the main political mediation by institutionalizing participation and deliberation. And, finally, a pragmatic democracy redesigns institutions in such a way as to blow the separation of state and civil society, as it happens when the latter act along with the state, and achieves that from within it.

Once endorsing constitutive representation, a pragmatic democracy must also experiment with forms of accountability that go beyond elections, democratic criteria other than the majority rule, and legitimating mechanisms able to transcend both by privileging ex post assessments (that is, assessments based on the consequences of decisions) rather than ex ante assessments (based on the choices of the decision maker). Political experimentalism makes it possible to deal with the problems of justification, evaluation and legitimacy of democracy on the basis of the consequences engendered by the actions of institutions and political actors. The true parameters for gauging democracy become the desirability, feasibility and acceptability of such consequences. That, in turn, brings one closer to a realistic practice of democracy, and not an idealized version thereof.

This approach must be further developed in order to account for the fact that Brazil's national policy conferences allow all those citizens and groups who are affected by the design of public policies and share the consequences of their implementation to have their interests represented in political institutions, despite their choices in a previous election. The conference process has been legitimizing itself as a democratic method through the positive effects it have been producing on political institutions, and this can be especially measured by the introduction of new areas and issues dealt with in 
policymaking, and by the inclusion of new groups and demands in the lawmaking.

Such cooperation among state and civil society, representative institutions and participatory practices, presents the national policy conferences as a method of pragmatic democracy in which social ends might be successfully realized through democratic experimental means. By bringing civil society within the state, the national public policy conferences shall be taken as both a form of deepening democracy and democratizing policymaking. The national level practices of participation in Brazil seem to be a very fertile soil where the germination of participation can lead to the blossoming of representation. Let the contingency of contemporary world tell us how liberal democracy can be definitely and decisively challenged by such experimental way of doing politics. And let Brazilian reality keeps teaching us lessons on that.

\section{References}

Avritzer, Leonardo (2007): "Sociedade Civil, Instituições Participativas e Representação: da Autorização à Legitimidade da Ação". In: Dados (Rio de Janeiro), 50, 3, pp. 443-464.

- (2009): Participatory Institutions in Democratic Brazil. Baltimore: Johns Hopkins University Press.

Barber, Benjamin (1984): Strong Democracy: Participatory Politics for a New Age. Berkeley: University of California Press.

Bohman, James (1996): Public Deliberation. Pluralism, Complexity, and Democracy. Cambridge: MIT Press.

Castiglione, Dario/Warren, Mark (2006): "Rethinking Democratic Representation: Eight Theoretical Issues". Manuscript prepared for delivery at the Centre for the Study of Democratic Institutions, University of British Columbia.

Cohen, Joshua (1997): "Deliberation and Democratic Legitimacy". In: Bohmann, James/Rehg, William (eds.): Deliberative Democracy. Essays on Reason and Politics. Cambridge: MIT Press, pp. 67-91.

Dewey, John ([1937] 1998): "Democracy is Radical". In: The Essential Dewey. Vol. I: Pragmatism, Education, Democracy. Bloomington: Indiana University Press, pp. 337-339.

Dryzek, John S. (2000): Deliberative Democracy and Beyond. Oxford: Oxford University Press.

Fishkin, James (1991): Democracy and Deliberation: New Directions for Democratic Reform. New Haven: Yale University Press. 
Fung, Archon/Wright, Erik Olin (2003): Deepening Democracy: Institutional Innovations in Empowered Participatory Governance. London: Verso.

Gutmann, Amy (1996): Democracy and Disagreement. Cambridge: Harvard University Press.

Habermas, Jürgen (1998): Between Facts and Norms. Contributions for a Discourse Theory of Law and Democracy. Cambridge: MIT Press.

Manin, Bernard (1996): Principes du Gouvernement Représentatif. Paris: CalmannLevy.

Mansbridge, Jane (2003): "Rethinking Representation". In: American Political Science Review, 97, 4, pp. 515-528.

Pogrebinschi, Thamy (2010a): Relatório Final da Pesquisa "Entre Participação e Representação: as conferências nacionais e o experimentalismo democrático brasileiro". Brasília: Ministério da Justiça.

- (2010b): "Democracia Pragmática". In: Dados, 53, 3, pp. 657-693.

- (2012): "Participation as Representation. Democratic Policymaking in Brazil". In: Cameron, Max/Hershberg, Eric/Sharpe, Kenneth: New Institutions for Participatory Democracy in Latin America. Voice and Consequence. Houndmills, Basingstoke: Palgrave Macmillan, pp. 53-75.

- (forthcoming): “Turning Participation into Representation: Innovative Policymaking for Minority Groups in Brazil". In: Sirianni, Carmen/Girouard, Jennifer (eds.): Varieties of Civic Innovation: Deliberative, Collaborative, Network, and Narrative Approaches. Nashville: Vanderbilt University Press. Forthcoming.

Pogrebinschi, Thamy/Santos, Fabiano (2010): "Participation as Representation: The Impact of National Public Policy Conferences on the Brazilian Congress". APSA 2010 Annual Meeting Paper.

Rosanvallon, Pierre (1998): Le people introuvable. Histoire de la representation démocratique en France. Paris: Gallimard.

- (2006): La contre-démocratie. La politique à l'âge de la defiance. Paris: Seuil.

Sintomer, Yves (2007): Le pouvoir au peuple. Jurys citoyens, tirage au sort et démocratie participative. Paris: La Découverte.

Urbinati, Nadia (2006): Representative Democracy: Principles and Genealogy. Chicago: Chicago University Press.

Urbinati, Nadja/Warren, Mark (2008): “The Concept of Representation in Contemporary Democratic Theory". In: Annual Review of Political Science, 11, pp. 387412. 